Zeszyty Naukowe Szkoły Głównej Gospodarstwa Wiejskiego

Ekonomika i Organizacja Gospodarki Żywnościowej nr 115, 2016: 151-161

Dominika Głąbska, Monika Borowska

Katedra Dietetyki

Szkoła Główna Gospodarstwa Wiejskiego w Warszawie

Dominika Guzek

Katedra Organizacji i Ekonomiki Konsumpcji

Szkoła Główna Gospodarstwa Wiejskiego w Warszawie

\title{
Wybory produktów żywnościowych przez dzieci w wieku szkolnym w kontekście zmian regulacji prawnych związanych ze sprzedażą produktów spożywczych w szkołach
}

\section{Wstęp}

Problem nieprawidłowego żywienia dzieci i młodzieży, a w konsekwencji, nadmiernej masy ciała (zarówno nadwagi, jak i otyłości) dotyczy całej Unii Europejskiej i stanowi jeden z najpoważniejszych problemów zdrowia publicznego [Ahrens i in. 2014]. W Europie co trzeci jedenastolatek ma nadwagę lub otyłość [WHO 2014]. W Stanach Zjednoczonych w 2012 roku, ponad jedna trzecia dzieci i młodzieży miała nadwagę lub otyłość [Ogden i in. 2014].

Skala problemu nadmiernej masy ciała wśród dzieci jest na tyle duża, że w Polsce zostały wprowadzone regulacje prawne mające na celu ograniczenie dostępności produktów spożywczych, które nie są zalecane w racjonalnym żywieniu dzieci i młodzieży [Rozporzadzenie...]. Wprowadzone rozporządzenie w sprawie grup środków spożywczych przeznaczonych do sprzedaży dzieciom i młodzieży w jednostkach systemu oświaty oraz wymagań, jakie muszą spełniać środki spożywcze stosowane w ramach żywienia zbiorowego dzieci i młodzieży w tych jednostkach, ma szczególne znacznie, jako że w przypadku wielogodzinnego pobytu dziecka w szkole właściwa oferta produktów spożywczych w sklepikach szkolnych może umożliwić prawidłowe wybory. Elementem uzupełniającym, ale nie mniej ważnym, powinna być edukacja żywieniowa jako element systemu kształcenia. 
Aktualnie obowiązujące, jednakże mające niedługo ulec zmianie, rozporządzenie Ministra Zdrowia z 2015 roku określa warunki, jakie musi spełniać zarówno żywność sprzedawana dzieciom i młodzieży w sklepikach szkolnych (załącznik 1 do tego rozporządzenia), jak i żywność podawana uczniom w szkolnych stołówkach (załącznik 2 do tego rozporządzenia). Pierwszy załącznik precyzuje produkty dopuszczone do sprzedaży w sklepikach szkolnych i, tym samym, ogranicza dostęp dzieci do środków spożywczych zawierających znaczne ilości tłuszczu (zawierające powyżej $10 \mathrm{~g}$ na $100 \mathrm{~g}$ gotowego do spożycia produktu), soli (dosalane lub zawierające więcej niż 0,12 g sodu lub równoważną ilość soli na $100 \mathrm{~g}$ lub $100 \mathrm{ml}$ ) i cukru (dosładzane lub zawierające więcej niż $10 \mathrm{~g}$ cukru na $100 \mathrm{~g}$ lub $100 \mathrm{ml}$ ), które spożywane w nadmiarze mogą być przyczyną chorób dietozależnych [Rozporządzenie...]. W konsekwencji zakaz sprzedaży w sklepikach szkolnych dotyczy m.in. słodyczy, chipsów, napojów energetyzujących czy dań typu fast food.

Zmiany regulacji prawnych, wymuszające zmianę dostępności niektórych produktów spożywczych w sklepikach szkolnych, mogą przyczynić się do zmian na rynku produktów spożywczych i zachęcić producentów do rozwoju środków spożywczych spełniających założenia wskazane w rozporządzeniu Ministra Zdrowia z 2015 roku. Skuteczność tego typu działań musi być jednak monitorowana, a informacja zwrotna powinna posłużyć do wdrożenia odpowiednich działań korygujących. Istotnym czynnikiem, który może przyczynić się do małej skuteczności podejmowanych działań może być niewystarczająca wiedza żywieniowa dzieci i ich rodziców, jako że sklepiki szkolne nie są jedynym miejscem, gdzie dzieci i ich rodzice mają możliwość nabyć produkty, które mogą przyczyniać się do nadmiernej masy ciała. Wyniki badań realizowanych w Stanach Zjednoczonych wskazują, że skutecznym działaniem, które przyczynia się do redukcji zjawiska otyłości wśród dzieci, jest zastosowanie programu edukacyjnego angażującego nie tylko dzieci, ale również rodziców i lokalne społeczności [Wright $i$ in. 2012].

Celem zaprezentowanej pracy była analiza wyborów produktów żywnościowych dokonywanych przez dzieci w wieku szkolnym w sklepach spożywczych i określenie różnic wyborów w grupach zależnych od masy ciała.

\section{Metodyka badań}

W badaniu przeprowadzonym w 2015 roku, zastosowano dobór celowy reprezentatywnej próby respondentów. Udział w nim wzięli uczniowie klas IV, V i VI ze Szkoły Podstawowej $10 \mathrm{im}$. Księżnej Aleksandry Ogińskiej w Siedlcach. Do wzięcia udziału w badaniu, zaplanowanym i przeprowadzonym za zgodą dy- 
rektora placówki, zaproszono 346 dzieci - wszystkich uczniów szkoły z klas IV-VI. Na wzięcie udziału przez dzieci w badaniu wyrazili pisemną, świadomą zgodę rodzice 194 dzieci. Ostatecznie dla 124 dzieci skompletowano całość wyników badań, tj. zmierzono ich masę, wzrost i zebrano poprawnie wypełniony formularz ankiety dotyczącej sposobu żywienia i wyboru produktów spożywczych. Formularz autorskiej ankiety zawierał pytania dotyczące sposobu żywienia. Respondenci byli w niej pytani m.in. o produkty spożywcze samodzielnie najczęściej kupowane w sklepach. Pytanie to dotyczyło wszystkich rodzajów sklepów spożywczych, w których ankietowanym zdarzało się kupować produkty tego rodzaju. Każdy $\mathrm{z}$ ankietowanych mógł wymienić do trzech określonych samodzielnie kupowanych produktów, przy czym proszeni byli oni o sprecyzowanie rodzaju produktu, a nie o wskazanie producenta czy nazwy handlowej.

Wśród 124 dzieci było 75 dziewcząt (60,5\%) i 49 chłopców (39,5\%) w wieku od 10 do 13 lat. Pomiar wzrostu i masy ciała został w badanej grupie przeprowadzony przez pielęgniarkę. Na tej podstawie wyliczono wskaźnik masy ciała BMI (ang. body mass index), dzieląc masę ciała (podano w kg) przez wzrost podniesiony do kwadratu (podano $\mathrm{w} \mathrm{m}^{2}$ ).

Dla oceny wskaźnika BMI posłużono się siatkami centylowymi BMI opracowanymi w ramach projektu OLAF dla polskich chłopców i dziewcząt w wieku 7-18 lat [Kułaga $i$ in. 2011]. Badani zostali podzieleni na grupy w kategoriach określających położenie BMI w siatkach centylowych. Analizowano dwa przypadki według odrębnych klasyfikacji podziału BMI. W klasyfikacji pierwszej określono trzy grupy $\mathrm{w}$ zależności od położenia BMI w siatkach centylowych: poniżej 25. centyla (27 osób), między 50. a 75. (53), powyżej 75. (44). W klasyfikacji drugiej zastosowano podział na 12 grup w zależności od położenia BMI w siatkach centylowych: poniżej 3. centyla (2 osoby), między 3. a 5. (2), między 5. a 10. (8), między 10. a 15. (10), między 15. a 25. (6), między 25. a 50. (19), między 50. a 75. (32), między 75. a 85. (13), między 85. a 90. (9), między 90. a 95. (13), między 95. a 97. (7), powyżej 97. (3).

\section{Metodyka analizy statystycznej}

Do porównania zmiennych o charakterze jakościowym wykorzystany został test chi ${ }^{2}$. Przy określaniu istotności statystycznej przyjęto poziom istotności $\alpha=0,05$, a poziom $\alpha=0,1$ wskazano jako bliski istotności statystycznej. Do prowadzenia analizy statystycznej wykorzystano program Statistica 10.0 (StatSoftInc.). 


\section{Wyniki i dyskusja}

\section{Środki spożywcze samodzielnie kupowane przez dzieci}

W tabeli przedstawiono produkty najczęściej deklarowane przez ankietowanych jako samodzielnie kupowane w sklepach spożywczych z uwzględnieniem podziału na trzy kategorie, biorąc pod uwagę położenie BMI w siatkach centylowych. W badanej grupie wśród najczęściej kupowanych samodzielnie produktów spożywczych wskazano przede wszystkim różne rodzaje słodyczy - cukierki, batony, wyroby cukiernicze, jak również napoje wysokosłodzone.

W badaniu Czajkowskiej-Fesio i Kurylak [2013], podobnie jak w badaniach własnych, wykazano, iż dzieci, uczęszczające do klas IV-VI szkoły podstawowej najczęściej kupowały do jedzenia słodycze ( $34 \%$ badanych). W tym badaniu przeprowadzonym wśród dzieci z Nakła nad Notecią ankietowani podali także inne produkty kupowane samodzielnie: kanapki (22\% badanych), żywność typu fast food (17\%), warzywa (8\%), bułki (8\%), owoce (7\%), drożdżówki (5\%), zaś $2 \%$ respondentów deklarowało, że nic nie kupuje [Czajkowska-Fesio i Kurylak 2013]. Warto wskazać szczególnie deklarowane przez badanych z Nakła nad Notecią kanapki, które przez dzieci z Siedlec nie były wcale deklarowane. Jednakże różnica ta wynikać może $\mathrm{z}$ dostępności do różnego rodzaju produktów spożywczych.

W badaniu Kujawskiej-Pac i innych [2014] poddano analizie produkty spożywcze deklarowane przez dzieci jako kupowane w sklepikach szkolnych. W ramach tego badania przeprowadzono, na przełomie 2011 i 2012 roku, ocenę w 50 losowo wybranych szkołach w Krakowie, w której stwierdzono, że uczniowie, niezależnie od szkoły, kupowali najczęściej słodkie bułki (26\% badanych), przekąski (19\%), słodkie napoje gazowane (12\%), galaretki i soki (7\%) oraz kanapki, słodycze i ciasta (5\%) [Kujawska-Pac i in. 2014].

Można zatem stwierdzić, że niezależnie od wielkości miasta, w którym realizowane są badania, jak również od tego, czy badanie dotyczyło produktów kupowanych w sklepikach szkolnych (na przełomie 2011 i 2012 roku), czy $\mathrm{w}$ innych sklepach spożywczych - zawsze najczęściej kupowanymi przez polskie dzieci produktami są różne rodzaje słodyczy. Może to wskazywać na to, że nawet jeśli produkty takie nie są dostępne w sklepikach szkolnych zgodnie z rozporządzeniem Ministra Zdrowia z 2015 roku, to dzieci kupuja je w innego rodzaju sklepach. Zarówno przytoczone badania, jak i wyniki badań własnych potwierdzają potrzebę nie tylko prawnej regulacji asortymentu produktów dostępnych w sklepikach szkolnych, ale także wprowadzenia powszechnej edukacji żywieniowej w szkołach, aby zwiększyć wiedzę dzieci i młodzieży oraz ich rodziców na temat zdrowego żywienia. 


\section{Tabela}

Deklarowane przez ankietowanych produkty samodzielnie najczęściej kupowane w sklepach spożywczych, z uwzględnieniem podziału na trzy kategorie biorąc pod uwagę położenie BMI w siatkach centylowych (możliwość wskazania do 3 produktów)

\begin{tabular}{|c|c|c|c|c|c|}
\hline \multirow{2}{*}{\multicolumn{2}{|c|}{ Wyszczególnienie }} & \multicolumn{3}{|c|}{$\begin{array}{c}\text { Ankietowani znajdujący się w siatkach } \\
\text { centylowych BMI }\end{array}$} & \multirow{3}{*}{$\begin{array}{c}\text { Wartość p } \\
0,0623^{*}\end{array}$} \\
\hline & & \multirow{2}{*}{$\begin{array}{c}\text { poniżej } \\
25 . \text { centyla } \\
{\left[\begin{array}{c}\% \text { wyboru } \\
\text { ogółem] } \\
(\mathrm{n}=27)\end{array}\right.} \\
34,1 \\
\end{array}$} & \multirow{2}{*}{$\begin{array}{c}\text { między } \\
25 . \text { a } 75 . \\
\text { centylem } \\
{[\% \text { wyboru }} \\
\text { ogółem] } \\
(\mathrm{n}=53) \\
15,1 \\
\end{array}$} & \multirow{2}{*}{ 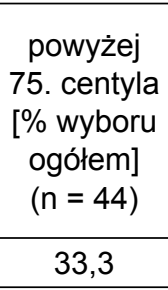 } & \\
\hline \multirow{6}{*}{ Słodycze } & cukierki & & & & \\
\hline & batony & 29,5 & 26,4 & 29,6 & 0,9278 \\
\hline & lody & 13,6 & 13,2 & 14,8 & 0,9805 \\
\hline & herbatniki & 4,5 & 3,8 & 7,4 & 0,7689 \\
\hline & czekolada & 2,3 & 1,9 & 7,4 & 0,3782 \\
\hline & słodycze & 9,1 & 13,2 & 11,1 & 0,8155 \\
\hline \multirow{3}{*}{ Napoje } & napoje słodzone & 40,9 & 34,0 & 33,3 & 0,7289 \\
\hline & woda & 27,3 & 11,3 & 7,4 & $0,0395^{\star *}$ \\
\hline & soki & 13,6 & 22,6 & 11,1 & 0,3299 \\
\hline \multirow{3}{*}{$\begin{array}{l}\text { Produkty } \\
\text { zbożowe }\end{array}$} & wyroby cukiernicze & 29,5 & 49,1 & 37,0 & 0,1410 \\
\hline & pieczywo & 2,3 & 11,3 & 3,7 & 0,1578 \\
\hline & płatki zbożowe & 2,3 & 0,0 & 0,0 & 0,3999 \\
\hline \multirow{2}{*}{$\begin{array}{l}\text { Słone } \\
\text { przekąski }\end{array}$} & chipsy & 20,5 & 18,9 & 18,5 & 0,9732 \\
\hline & popcorn & 2,3 & 0,0 & 0,0 & 0,3999 \\
\hline \multirow{2}{*}{$\begin{array}{l}\text { Owoce } \\
\text { i warzywa }\end{array}$} & owoce & 15,9 & 15,1 & 11,1 & 0,8456 \\
\hline & warzywa & 2,3 & 1,9 & 0,0 & 0,7451 \\
\hline \multirow{3}{*}{$\begin{array}{l}\text { Produkty } \\
\text { mleczne }\end{array}$} & przetwory mleczne & 11,4 & 18,9 & 11,1 & 0,4932 \\
\hline & mleko & 4,5 & 3,8 & 0,0 & 0,5498 \\
\hline & mleko smakowe & 2,3 & 7,5 & 0,0 & 0,2041 \\
\hline \multirow{3}{*}{ Inne } & wędlina & 4,5 & 0,0 & 3,7 & 0,3096 \\
\hline & orzechy & 2,3 & 1,9 & 3,7 & 0,8797 \\
\hline & dania garmażeryjne & 0,0 & 3,8 & 3,7 & 0,4293 \\
\hline \multicolumn{2}{|l|}{$\mathrm{Nic}$} & 2,3 & 0,0 & 0,0 & 0,3999 \\
\hline \multicolumn{2}{|c|}{ Brak odpowiedzi } & 6,8 & 1,9 & 3,7 & 0,4676 \\
\hline
\end{tabular}

Analiza zmiennych jakościowych - test $\operatorname{chi}^{2}$ przy ${ }^{*} \alpha=0,1,{ }^{* *} \alpha=0,05$.

Źródło: Badania własne. 


\section{Związek między samodzielnym zakupem wody a masą ciała dzieci}

W przeprowadzonym badaniu własnym stwierdzono istotne statystycznie różnice dotyczące samodzielnego dokonywania zakupu wody między osobami należącymi do różnych grup w zależności od położenia w siatkach centylowych BMI $(p=0,0395)$. Największy udział dzieci deklarował kupowanie wody w przypadku ankietowanych znajdujących się w siatkach centylowych BMI poniżej 25. centyla, zaś najmniejszy udział - w przypadku osób znajdujących się powyżej 75. centyla.

Można wskazać również badania innych autorów dotyczące zależności między spożyciem wody a masą ciała u dzieci. Muckelbauer i inni [2009] przeprowadzali badanie w grupie 2950 dzieci z 32 szkół podstawowych, w którym określano skuteczność wpływu edukacji dotyczącej spożycia wody na zmniejszenie masy ciała u dzieci szkolnych. Podkreślić należy, iż w badaniu Muckelbauer i innych [2009] obie grupy badane (edukowana - 1641 osób i nieedukowana 1309 osób) miały nieograniczony dostęp do wody w szkole przez cały okres trwania badania, a jedynie grupa kontrolna nie brała udziału w kilku spotkaniach edukacyjnych dotyczących znaczenia spożycia i roli wody dla organizmu. Po przeprowadzonej edukacji trwającej przez cały rok szkolny stwierdzono, że częstość występowania nadwagi, w porównaniu z grupą kontrolna, w grupie badanej była mniejsza o $31 \%$, a równocześnie spożycie wody u dzieci po edukacji wzrosło średnio o 1,1 szklanki dziennie [Muckelbauer i in. 2009]. W badaniu Dubuisson i innych [2012], w którym przeprowadzono retrospektywną ocenę interdyscyplinarnego programu leczenia otyłości, również wykazano korzystny wpływ spożycia wody przez dzieci z nadmierną masą ciała. $\mathrm{W}$ badaniu, do którego zostały zakwalifikowane dzieci objęte programem przez minimum rok, wykazano, iż osoby z wysokim poziomem aktywności fizycznej i codziennie spożywające wodę, w porównaniu do tych niespożywających wody, po 9 miesiącach uzyskały efekt redukcji masy ciała [Dubuisson i in. 2012].

\section{Związek między samodzielnym zakupem cukierków a masą ciała dzieci}

Kolejnym kupowanym produktem spożywczym, w przypadku którego obserwowano różnice między podgrupami, były cukierki (różnice te były bliskie istotności statystycznej $(\mathrm{p}=0,0623)$. Stwierdzono, że spożycie cukierków najrzadziej deklarowały osoby znajdujące się w siatkach centylowych BMI między 25. a 75. centylem. W przypadku pozostałych produktów spożywczych kupowanych samodzielnie nie stwierdzono w badanej grupie różnic istotnych statystycznie, ani bliskich istotności statystycznej. 
Mimo tego, że fakt częstszego wyboru cukierków przez dzieci z największymi wartościami BMI, (w porównaniu z dziećmi z wartościami BMI znajdującymi się między 25. a 75 centylem) może być w pierwszej chwili uznany za spodziewany, to należy podkreślić, że w badaniach innych autorów taka zależność nie jest stwierdzana. O’Neil i inni [2015] w ramach badania Bogalusa Heart Study wykazali, że spożycie cukierków w dzieciństwie nie jest skorelowane ze wskaźnikiem BMI w wieku dorosłym. Równocześnie w analizie, realizowanej w ramach badania NHANES (ang. National Health and Nutrition Examination Survey) 1999-2004, w grupie ponad 15 tys. dorosłych mieszkańców Stanów Zjednoczonych, O’Neil i inni [2011a] stwierdzili, że spożycie cukierków nie jest związane z większą masą ciała ani z większymi wartościami wskaźnika BMI.

Równocześnie fakt częstszego wyboru cukierków przez dzieci z najmniejszymi wartościami BMI (w porównaniu z dziećmi o BMI $=25-75$ centyli) znajduje potwierdzenie w danych literaturowych. Analiza zrealizowana przez O'Neil i innych [2011b], dotycząca m.in. zależności między spożyciem cukierków przez dzieci zamieszkałe na terenie Stanów Zjednoczonych a ich masą ciała, zrealizowana w ramach badania NHANES 1999-2004, wskazała że dzieci, które spożywają cukierki charakteryzują się mniejszymi BMI i obwodu talii niż dzieci, które nie spożywają cukierków. Może być to związane z tym, że dzieci te i ich rodzice są świadomi małej masy ciała i przyjmują, że zwiększenie spożycia cukierków jest dobrym sposobem na zwiększenie jej.

W badaniu własnym, przy porównaniu produktów wskazanych przez dzieci jako kupowane samodzielnie, między 12 grupami obserwowano istotne statystycznie różnice dla produktów, takich jak: wędlina $(\mathrm{p}=0,0081)$, cukierki $(\mathrm{p}=0,0133)$, dania obiadowe $(\mathrm{p}=0,0055)$. Stwierdzono, że samodzielne kupowanie cukierków nie jest deklarowane przez ankietowanych z przedziałów poniżej 3. centyla, między 75. a 80. oraz 95. a 97. centylem. Należy jednak podkreślić, że w przypadku dzieci z najmniejszą spośród badanych masą ciała deklarujących całkowite niespożywanie cukierków, deklaracja ta może być związana z celowym ich unikaniem. Jak wskazują wyniki badań, coraz poważniejszym problemem nie tylko wśród nastolatków, ale i dzieci są związane z zaburzeniami odżywiania podejmowane samodzielnie próby redukcji masy ciała, wynikające $\mathrm{z}$ chęci osiągnięcia bardzo szczupłej sylwetki [Morris i Katzman 2003].

\section{Związek między samodzielnym zakupem wędlin i dań garmażeryjnych a masą ciała dzieci}

W badanej grupie, przy porównaniu produktów wskazanych przez dzieci jako kupowane samodzielnie, między 12 grupami stwierdzono, że samodzielne kupowanie wędlin deklarowane jest jedynie przez ankietowanych z przedzia- 
łów między 3. a 5. oraz 85. a 90. centylem, a dań obiadowych - deklarowane jest jedynie przez ankietowanych z przedziałów między 25 . a 50., 75. a 80. oraz 95. a 97. centylem. Podkreślić przede wszystkim należy, że kupowanie zarówno wędlin, jak i dań garmażeryjnych było deklarowane przez badanych o dużych wartościach BMI (wartości położone w siatkach centylowych między 75. a 97. centylem).

Podobne wyniki obserwowano w badaniu Santos i innych [2014], w którym oceniano wpływ wzorców żywieniowych na ryzyko występowania podwyższonego BMI wśród brazylijskich dzieci i młodzieży. W badaniu tym wskazano m.in. sprzyjającą otyłości rolę takich produktów, jak typowe brazylijskie dania, produkty typu fast food, sosy, oleje. Podobne wyniki uzyskali również Silva i inni [2012] oraz Leal i inni [2010], oceniając wzorce żywieniowe wśród populacji brazylijskiej. Autorzy stwierdzili, iż zwiększone spożycie produktów przetworzonych oraz produktów zawierających duże ilości thuszczu ogółem i nasyconych kwasów tłuszczowych może przyczyniać się do nadmiernej masy ciała. Koresponduje to $\mathrm{z}$ wynikami badań własnych i wskazanymi przez badanych wędlinami i daniami garmażeryjnymi.

\section{Związek między samodzielnym zakupem chipsów a masą ciała dzieci}

W badaniu własnym, przy porównaniu produktów wskazanych przez dzieci jako kupowane samodzielnie, między 12 grupami badanych obserwowano również bliskie istotności statystycznej różnice dotyczące deklarowanego kupowania chipsów $(\mathrm{p}=0,0702)$. Ich samodzielne kupowanie przez przynajmniej połowę badanych było deklarowane wyłącznie w grupach dzieci z największymi wartościami BMI (między 95. a 97. centylem oraz powyżej 97. centyla). Podobne wyniki uzyskano w badaniu Mocanu [2013], w którym w grupie 3444 dzieci w wieku 6-10 lat, mieszkających w Rumunii, określano związek między statusem socjoekonomicznym oraz spożyciem chipsów i frytek a występowaniem nadmiernej masy ciała. W badaniu tym wykazano, że zarówno wysokim status socjoekonomiczny, jak i spożywanie chipsów i frytek były związane z podwyższonym ryzykiem nadwagi, oraz że w podgrupach dzieci o wysokim i średnim statusie socjoekonomicznym spożycie chipsów i frytek było pozytywnie skorelowane $\mathrm{z}$ występowaniem nadmiernej masy ciała [Mocanu 2013]. Analogiczne wnioski wyciągnęli McDonald i inni [2009] w badaniu obejmującym 3075 dzieci w wieku 5-12 lat, mieszkające w Kolumbii, w którym stwierdzono, że częstość spożywania przez dzieci słonych przekąsek była skorelowana z częstością występowania nadmiernej masy ciała. 


\section{Podsumowanie}

W badaniach własnych przeprowadzonych na próbie dzieci z klas IV-VI stwierdzono istotny związek kupowanych samodzielnie produktów spożywczych z masą ciała. Wykazano, że dzieci z dużą masą ciała najrzadziej kupowały samodzielnie wody, ale równocześnie - najczęściej chipsy, wędliny i dania garmażeryjne. Stwierdzono również, że najczęstsze samodzielne kupowanie cukierków deklarują respondenci z małym (ale nie najniższymi) i dużymi wartościami wskaźnika masy ciała, a nie jest to deklarowane przez ankietowanych z przeciętną masą ciała. Wykazano ponadto, że niezależnie od oceny masy ciała do najczęściej kupowanych samodzielnie produktów spożywczych zaliczane są różnego rodzaju słodycze - cukierki, batony oraz wyroby cukiernicze, a także napoje wysokosłodzone. Można zatem wnioskować, że uwzględniając fakt kupowania przez dzieci tych produktów w różnych sklepach, a nie tylko sklepikach szkolnych, konieczna jest nie tylko regulacja prawna dotycząca asortymentu produktów spożywczych dostępnych w sklepikach szkolnych, ale również edukacja dzieci i ich rodziców.

\section{Literatura}

AHRENS W., PIGEOT I., POHLABELN H., DE HENAUW S., LISSNER L., MOLNÁR D., MORENO LA., TORNARITIS M., VEIDEBAUM T., SIANI A., IDEFICS CONSORTIUM., 2014: Prevalence of overweight and obesity in European children below the age of 10, International Journal of Obesity 38, 99-107.

CZAJKOWSKA-FESIO J., KURYLAK A., 2013: Ocena nawyków żywieniowych, aktywności fizycznej i troski o zdrowie w hierarchii uczniów klas IV-VI Szkoty Podstawowej nr 3 w Nakle nad Notecia, Pielęgniarstwo Polskie 4, 262-269.

DUBUISSON A.C., ZECH F.R., DASSY M.M., JODOGNE N.B., BEAULOYE V.M., 2012: Determinants of weight loss in an interdisciplinary long-term care program for childhood obesity, International Scholarly Research Notices Obesity 349384, http://dx.doi. org/10.5402/2012/349384.

KUJAWSKA-PAC U., KWILOSZ E., MAZUR A., 2014: Ocena żywności oferowanej w sklepikach szkolnych $i$ kupowanej przez dzieci z krakowskich szkót podstawowych, Pediatria Polska 89 (5), 347-351.

KUŁAGA Z., LITWIN M., TKACZYK M., PALCZEWSKA I., ZAJĄCZKOWSKA M., ZWOLIŃSKA D., KRYNICKI T., WASILEWSKA A., MOCZULSKA A., MORAWIEC-KNYSAK A., BARWICKA K., GRAJDA A., GURZKOWSKA B., NAPIERALSKA E., PAN H., 2011: Polish 2010 growth references for school-aged children and adolescents, European Journal of Pediatrics 170 (5), 599-609.

LEAL G.V.S., PHILIPPI S.T., MATSUDO S.M.M., TOASSA E.C., 2010: Consumo alimentar e padrão de refeições de adolescentes, São Paulo, Brasil, Revista Brasileira de Epidemiologia 13, 457-467. 
McDONALD C.M., BAYLIN A., ARSENAULT J.E., MORA-PLAZAS M., VILLAMOR E., 2009: Overweight is more prevalent than stunting and is associated with socioeconomic status, maternal obesity, and a snacking dietary pattern in school children from Bogotá, Colombia, Journal of Nutrition 139 (2), 370-376.

MOCANU V., 2013: Prevalence of overweight and obesity in urban elementary school children in northeastern Romania: its relationship with socioeconomic status and associated dietary and lifestyle factors, BioMed Research International 537451.

MORRIS A.M., KATZMAN D.K., 2003: The impact of the media on eating disorders in children and adolescents, Paediatrics and Child Health 8 (5), 287-289.

MUCKELBAUER R., LIBUDA L., CLAUSEN K., TOSCHKE A.M., REINEHR T., KERSTING M., 2009: Promotion and provision of drinking water in schools for overweight prevention: randomized, controlled cluster trial, Pediatrics 123, 661-667.

OGDEN C.L., CARROLL M.D., KIT B.K., FLEGAL K.M., 2014: Prevalence of childhood and adult obesity in the United States, 2011-2012, Journal of the American Medical Association $311(8), 806-814$.

O’NEIL C.E., FULGONI V.L. 4III., NICKLAS T.A., 2011a: Association of candy consumption with body weight measures, other health risk factors for cardiovascular disease, and diet quality in US children and adolescents: NHANES 1999-2004, Food \& Nutrition Research 55, DOI: 10.3402/fnr.v55i0.5794.

O’NEIL C.E., FULGONI V.L. 4III., NICKLAS T.A., 2011b: Candy consumption was not associated with body weight measures, risk factors for cardiovascular disease, or metabolic syndrome in US adults: NHANES 1999-2004, Food \& Nutrition Research 31, 122-130.

O’NEIL C.E., NICKLAS T.A., LIU Y., BERENSON G.S., 2015: Candy consumption in childhood is not predictive of weight, adiposity measures or cardiovascular risk factors in young adults: the Bogalusa Heart Study, Journal of Human Nutrition and Dietetics 28 (2), 59-69.

Rozporzqdzenie Ministra Zdrowia z dnia 26 sierpnia 2015 r. w sprawie grup środków spozywczych przeznaczonych do sprzedaży dzieciom i młodzieży w jednostkach systemu oświaty oraz wymagań, jakie musza spetniać środki spożywcze stosowane $w$ ramach żywienia zbiorowego dzieci i młodzieży w tych jednostkach (Dz.U. 2015, poz. 1256).

SANTOS N.H.A., ROSEMEIRE LEOVIGILDO FIACCONE R.L., BARRETO M.L., ALVES DA SILVA L., SILVA R.R., 2014: Association between eating patterns and body mass index in a sample of children and adolescents in Northeastern Brazil, Cadernos de Saúde Pública 30, 2235-2245.

SILVA R.C.R., ASSIS A.M.O., SZARFARC S.C., PINTO E., COSTA L.C.C., RODRIGUES L.C., 2012: Iniquidades socioeconômicas na conformação dos padrões alimentares de crianças e adolescents, Annual Review of Nutrition 25, 451-461.

WHO, 2014: Data and statistics. The challenge of obesity - quick statistics, dostępne on-line na http://www.euro.who.int/en/health-topics/noncommunicable-diseases/obesity/dataand-statistics (dostęp: 12.05.2016).

WRIGHT K., NORRIS K., NEWMAN GIGER J., SURO Z., 2012: Improving healthy dietary behaviors, nutrition knowledge, and self-efficacy among underserved school children with parent and community involvement, Childhood Obesity 8 (4), 347-56. 


\title{
Abstrakt
}

Celem badania była analiza wyboru produktów żywnościowych, dokonywanych przez dzieci w wieku szkolnym w zależności od masy ciała. W badaniu udział wzięło 75 dziewcząt i 49 chłopców (10-13 lat), podzielonych na grupy zależne od położenia wskaźnika masy ciała (BMI) w siatkach centylowych. Dzieci zostały zapytane o samodzielnie kupowane produkty spożywcze. Do najczęściej kupowanych przez nie produktów spożywczych zaliczyć należy słodycze, ale kupowanie cukierków respondenci z prawidłową masą ciała deklarowali rzadziej niż ci z dużą lub małą wartością BMI. Dzieci z dużą masą ciała najrzadziej kupowały wody, ale równocześnie najczęściej chipsy, wędliny i dania garmażeryjne. Stwierdzono, że wybór produktów spożywczych jest związany z ich masą ciała. Wskazano, że konieczna jest nie tylko prawna regulacja asortymentu sklepików szkolnych, ale również edukacja.

Slowa kluczowe: wybory produktów żywnościowych, dzieci, masa ciała, słodycze, woda

\section{Food products choices made by schoolchildren in the context of changes of the legal regulations associated with selling food products in schools}

\begin{abstract}
The aim of the study was to analyze the food choices made by schoolchildren, depending on their body mass. In the study participated 75 girls and 49 boys aged $10-13$, who were divided into groups characterized by various body mass index (BMI) in comparison with child growth standards. The children were asked about food products bought on their own. Among the most frequently bought foods were sweet products, but buying sweets was less commonly declared by those with proper body mass than by those with high and low BMI. High body mass children least commonly bought water, but simultaneously - most commonly chips, cold cuts and ready-to-cook meals. It was stated that food choices are associated with body mass. It was indicated that not only legal regulation of assortment of food products available in schools is needed, but education as well.
\end{abstract}

Key words: food products choices, school children, body mass, sweet products, water 